\section{Estudo clínico-epidemiológico da malária falciparum em crianças de 0 a 14 anos, atendidas no Instituto de Medicina Tropical do Amazonas, AM, Brasil}

O estudo da malária falciparum em crianças é importante em função da morbidade e da mortalidade associadas à infecção nos trópicos e do desenvolvimento e disseminação de cepas de $P$. falciparum resistentes às múltiplas drogas. O objetivo do trabalho foi estudar as características clínicas e epidemiológicas da malária falciparum, em crianças de zero a 14 anos de idade, atendidas por demanda espontânea em um centro de referência (IMT-AM), em Manaus, AM, Brasil, no período de outubro a dezembro de 1997. Realizou-se um estudo descritivo com uma amostra de 61 pacientes que foram acompanhados através de avaliação clínica e parasitológica nos dias $0,3,5,7,14$, 21,28 e 35 . As crianças foram submetidas à anamnese e ao exame físico detalhado.O tratamento foi realizado de acordo com o protocolo do IMT-AM, sendo indicada a mefloquina como primeira linha e artesunato ou artemether na gravidade. Adotaram-se os critérios da OMS de malária grave e complicada. Amostras de sangue foram coletadas para: quantificação da parasitemia em gota espessa, dos leucócitos totais e das plaquetas, avaliação do hematócrito, dosagem de hemoglobina, glicose, uréia, creatinina, transaminases, bilirrubinas, bem como de pesquisa de anticorpos anti-P. falciparum e anti- $P$. vivax. Amostras fecais também foram obtidas para o exame parasitológico. Cinqüenta e oito crianças $(95,1 \%)$ apresentaram malária não complicada. A prevalência de malária grave foi $4,9 \%$ e a letalidade $1,6 \%$, correspondendo a uma criança falecida com complicações pulmonares. Foram identificados alguns fatores relacionados com a maior exposição à malária, tais como: domicílio rural e condições de moradia favoráveis, profissão dos pais (agricultores), hábito de deslocamentos freqüentes dos moradores de área urbana e baixo grau de proteção individual. Os sintomas relatados

\section{Clinical and epidemiological study of falciparum malaria in children between ages of 0 and 14 treated at the hospital of the Instituto de Medicina Tropical do Amazonas, AM, Brazil}

The study of falciparum malaria infection in children is important because it is the major cause of childhood morbidity and mortality in the tropics, and of the development and spread of multidrug resistance. The aim of this report was to study the clinical and epidemiological characteristics of malaria falciparum in Amazonian children between the ages of 0 and 14 treated at the hospital of the Instituto de Medicina Tropical do Amazonas - Manaus (IMT-AM) in the State of Amazonas, Brazil, from October to December of 1997. This descriptive study includes a evaluation of 61 children, observed at days $0,3,5,7,14$, 21, 28 and 35. A detailed anamnesis and physical examination was carried out on all children. The IMT-AM protocol was followed for the management of the patients. In first line, mefloquine was introduced for uncomplicated cases and artesunate or artemether for severe malaria. All children were assessed according to the WHO criteria for severe and complicated malaria. Blood samples were taken to determine the parasite burden, the white-cell and the platelet count, the hematocrit and hemoglobin concentration and sera glucose, urea, creatinine, AST, ALT, bilirubin and levels of antibodies against $P$. falciparum and $P$. vivax. Stools were examined for parasites. Fifty-eight patients (91.5\%) had uncomplicated malaria. The prevalence of severe malaria was $4.9 \%$. The lethality rate in this group of children was low (1.6\%). One child died of respiratory complications. Among the risk factors found for malarial infection we could indicate: residence in a rural locality, housing conditions, the parents' occupations, high mobility of the population living in Manaus and inadequate personal protective habits. Symptoms were the same as the ones found in adults: fever, headache, chills, sweating and myalgia. Seizures occurred in $8.2 \%$ of the children but in this situation only $3.2 \%$ were attributed to the plasmodium. 
foram semelhantes aos verificados em adultos, sendo freqüente a presença de febre, cefaléia, calafrios, sudorese e mialgia. Convulsões ocorrerram em $8,2 \%$ das crianças, sendo relacionadas exclusivamente ao $P$. falciparum em 3,2\%. Os testes sorológicos não contribuíram para as correlações clínico-imunológicas. A anemia $(54,5 \%)$ apresentou forte associação com os maiores níveis de parasitemia $(p=0,006)$, assim como a presença de palidez cutâneomucosa e de anemia apresentaram relação com a baixa idade (0 a 4 anos). Os índices de cura clínica e parasitológica foram 276 e 277 casos por 1000 pacientes/dia, respectivamente. Nos pacientes tratados com mefloquina, a incidência de resistência do tipo RIII foi $5,9 \%$ e as razões cura/resistência e cura/gravidade foram 20:1 e $62: 1$, respectivamente. O estudo contribuiu para o melhor conhecimento das manifestações clínicas da malária falciparum em crianças atendidas no IMT-AM, revelando a importância da freqüência de anemia nas crianças menores de 4 anos e da resistência à mefloquina com padrão RIII (5,9\%).
Antibody levels were not proportional to clinical manifestations. Anemia (54.5\%) was strongly associated with high levels of parasitemia $(p=0.006)$. Pallor and anemia were found more frequently in children aged 0-4. The incidences of clinical and parasitic cure were 276 and 277 cases/1000 patients/day. In patients treated with mefloquine, the incidence of resistance RIII was $5.9 \%$ and the cure/resistance ratio was $20: 1$. The cure/severity ratio was $62: 1$. These results are very useful in understanding the clinical features of falciparum malaria disease in children treated at the IMT-AM, as they show the importance of anemia in children aged 0-4 years old, and the occurrence of resistance (RIII) to mefloquine in children (5.9\%).

\section{Elza Ferreira Noronha}

Tese apresentada ao Núcleo de Medicina Tropical e

Nutrição da Universidade de Brasília para obtenção do Título de Mestre.

Brasília, DF, Brasil, 1999 